\title{
PENGARUH KUALITAS LAYANAN TERHADAP KEPUASAN NASABAH PADA PT. MANDALA MULTI FINANCE CABANG PALU
}

\author{
DEWI \\ H.CHALIL \\ H.SYAMSULBAHRI \\ Program Studi S1 Manajemen, Fakultas Ekonomi Universitas Tadulako \\ Email : dewitan071296@gmail.com
}

\begin{abstract}
The purpose of this study is to determine the effect of service quality on customer satisfaction at PT. Mandala Multi Finance Palu Branch. The sample used is 90 respondents, with sampling technique used is purposive sampling. Method of data analysis used in this research is Multiple Linear Regression. The results showed that service quality variables consisting of physical evidence, empathy, reliability, responsiveness, and collateral simultaneously have a significant effect on customer satisfaction at PT. Mandala Multi Finance Palu Branch. While the partial physical evidence, empathy, kahandalan, responsiveness, and guarantee also significantly affect customer satisfaction at PT. Mandala Multi Finance Palu Branch.
\end{abstract}

Keywords: Service quality, Customer Satisfaction

\begin{abstract}
ABSTRAK
Tujuan dari penelitian ini yaitu untuk mengetahui pengaruh kualitas layanan terhadap kepuasan nasabah pada PT. Mandala Multi Finance Cabang Palu. Sampel yang digunakan penelitian ini yaitu sebanyak 90 responden, dengan teknik penarikan sampel yang digunakan adalah purposive sampling.Metode analisis data yang digunakan dalam penelitian ini adalah Regresi Linear Berganda. Hasil penelitian menunjukkan bahwa variabel kualitas layanan yang terdiri bukti fisik, empati, kahandalan, daya tanggap,dan jaminan secara serempak berpengaruh signifikan terhadap kepuasan nasabah pada PT. Mandala Multi Finance Cabang Palu. Sedangkan secara parsial bukti fisik, empati, kahandalan, daya tanggap,dan jaminan juga berpengaruh signifikan terhadap kepuasan nasabah pada PT. Mandala Multi Finance Cabang Palu.
\end{abstract}

Kata Kunci: Kualitas Layanan, Kepuasan Nasabah

\section{PENDAHULUAN}

Industri jasa keuangan saat ini dihadapkan pada persaingan yang sangat tajam, kompleks dan perubahan lingkungan bisnis yang cepat.Persaingan menjadi semakin ketat untuk memperebutkan nasabah pada pasar yang sama,dalam mempersiapkan diri menghadapi persaingan tersebut, maka perusahaan yang menawarkan jasa keuangan harus jeli dalam melihat peluang pasar serta keinginan dan kebutuhan dari nasabah. Perusahaan yang ingin berkembang dan mendapatkan keunggulan kompetitif harus dapat memberikan jasa berkualitas dengan biaya yang lebih murah dan dapat memuaskan kebutuhan nasabah sehingga timbul kepuasan. Industri pembiayaan sekarang ini sangat bertumpuh kepada kualitas teknologi informasi yang digunakan oleh setiap perusahaan yang mempunyai kemampuan teknologi yang digunakan yang setara. Persamaan produk, fitur, atau kemudahan pelayanan menjadikan suatu industri yang bersifat homogen. Untuk memenangkan persaingan dalam industri ini, salah satu cara adalah menyediakan jenis dan kualitas layanan yang bisa membedakan dengan yang lain.

Nasabah cenderung memperhatikan kinerja pelayanan dalam memilih suatu perusahaan pembiayaan. Itulah sebabnya tidak mengherankan lagi jika pada kenyataannya persaingan perusahaan 
pembiayaan tidak lagi ditentukan oleh harga jual produk yang ditawarkan kepada pelanggan, tetapi lebih kepada kinerja pelayanan. Kesuksesan pemasaran perusahaan pembiayaan dapat dicapai melalui pemfokusan pada kualitas layanan untuk memuaskan pelanggan. Menurut Parasuraman (Schiffman \& Kanuk 2008:164).Pelayanan yang berkualitas yang menjadi faktor terpenting dalam menentukan kepuasan pelanggan sehingga pelanggan akan merasa bahwa keberadaannya memang dibutuhkan dan diperhatikan. Kepuasan pelanggan akan menumbuhkan dan meningkatkan loyalitas pelanggan. Bahkan karena loyalitasnya, pelanggan rela untuk merekomendasikan perusahaan tersebut. Jika pelanggan puas dan loyal akan mengakibatkan incomeperusahaan meningkat. Ada dua faktor utama yang mempengaruhi kualitas jasa tersebut adalah expected service (jasa yang didapat). Apabila jasa yang diterima nasabah sudah sesuai dengan jasa yang diinginkannya, maka kualitas jasa tersebut dianggap baik dan memuaskan. Dilain pihak, bila jasa yang diterima ternyata belum sesuai dengan jasa yang diinginkan, maka kualitas jasa tersebut belum dikatakan baik.

Kota Palu sebagai Ibu Kota Provinsi Sulawesi Tengah dan juga termasuk salah satu Kota urban di indonesia memiliki penduduk dengan tingkat mobilisasi yang tinggi sehingga kebutuhan masyarakat terhadap jasa leasing guna memudahkan kebutuhan mereka menjadi salah satu kebutuhan yang cukup penting terutama bagi para pengguna sepeda motor.Beberapa perusahaan jasa leasing di Kota Palu yang bersaing ketat untuk melayani para nasabah diKota Palu, antara lain:KP(Kredit Plus),dan Smart Finance. Masing-masing perusahaan jasa leasing tersebut berusaha memperkuat posisi mereka di mata konsumen serta terus berusaha menciptakan inovasi terhadap jasa penyewa kendaraan roda dua yang mereka tawarkan, salah satu strategi yang dilakukan pemilik perusahaandalam mempertahankan atau meningkatkan jumlah nasabah adalah dengan memberikan pelayanan yang berkualitas,dengan kualitas pelayanan yang optimal, di harapkan akan mampu memenuhi harapan dari konsumennya dan memenangkan persaingan yang pada akhirnya akan memperoleh laba yang maksimal.Berikut ini tabel 1 yang menguraikan jumlah nasabah perusahaan leasing di Kota Palu periode 2014-2016.

Tabel 1

Jumlah Nasabah Perusahaan Leasing di Kota Palu periode 2014-2016

\begin{tabular}{|c|c|c|c|c|}
\hline \multirow{2}{*}{ Perusahaan } & \multicolumn{3}{|c|}{ Tahun } & \multirow{2}{*}{ Jumlah } \\
\cline { 2 - 4 } & 2014 & 2015 & 2016 & \\
\hline Kredit Plus (KP) & $\mathbf{2 6 8 0}$ & $\mathbf{2 7 5 0}$ & $\mathbf{2 7 5 0}$ & $\mathbf{8 2 6 0}$ \\
\hline Smart Finance & - & - & 1600 & 1600 \\
\hline PT. Mandala & 1400 & 1100 & $\mathbf{8 0 0}$ & $\mathbf{3 . 2 0 0}$ \\
Multi Finance & & & & \\
\hline
\end{tabular}

Sumber: Data Primer

Berdasarkan tabel 1 diatas, terlihat bahwa jumlah nasabah PT. Mandala Multi Finance Cabang Palu, bisa dilihat pada tahun 2014-2016 mengalami penurunan setiap tahunnya sebanyak 300 nasabah. Sehingga PT. Mandala Multi Finance Cabang Palu perlu melakukan peningkatan strategi pemasaran antara laindengan cara meningkatkan kualitas layanan yang diharapkan oleh nasabah. Kualitas layanan tentu saja tidak hanya sebatas senyum ramah dari karyawan PT. Mandala Multi Finance Cabang Palu, melainkan lebih dari itu.Menurut Lupiyoadi, (2013:216) terdapat lima dimensi utama yang relevan untuk menjelaskan kualitas pelayanan yang dikenal dengan service quality (servqual) yaitu, bukti fisik, empati, kehandalan, dayat anggap, dan jaminan. Kelima dimensi kualitas pelayanan tersebut merupakan kunci utama untuk meningkatkan kepuasan nasabah. Hal inilah yang menjadi alasan penulis untuk melakukan penelitian pada PT. Mandala Multi Finance Cabang Palu yang berjudul "Pengaruh Kualitas Layanan Terhadap Kepuasan Nasabah Pada PT.Mandala Multi Finance Cabang Palu”. 


\section{KAJIAN LITERATURE DAN PENGEMBANGAN HIPOTESIS}

\section{Kualitas Layanan}

Kualitas layanan sangat erat kaitannya dengan kepuasan konsumen. Kualitas dapat memberikan dorongan kepada pelanggan untuk menjalin hubungan dengan perusahaan, dalam jangka panjang hubungan yang berjalan dapat memungkinkan perusahaan untuk memahami dengan seksama harapan pelanggan dan kebutuhan mereka. Kualias layanan dangat dipengaruhi oleh harapan konsumen. Tjiptono (2011:52) berpendapat kualitas pelayanan adalah tingkat keunggulan yang diharapkan dan pengendaliannya atas tingkat keunggulan tersebut untuk memenuhi keinginan pelanggan,dalam Kotler \&Keller (2009:143) kualitas adalah totalitas fitur dan karakteristik produk dan jasa yang bergantung pada kemampuan untuk memuaskan kebutuhan yang dinyatakan atau tersirat. Berdasarkan beberapa pengertian diatasyang membahas tentang kualitas pelayanan, dapat disimpulkan bahwa kualitas pelayanan adalah segala sesuatu yang diharapkan oleh konsumen agar perusahaan dapat memenuhi keinginan dan kebutuhan konsumen.

Menurut Lovelock(2011:154)mengelompokkan kualitas pelayanan sebagai berikut:

1. Bukti fisik (tangibles), berkenaan dengan daya tarik fasilitas fisik, perlengkapan, dan material yang digunakan perusahaan, serta penampilan karyawan.

2. Empati (empathy), berarti perusahaan memahami masalah para pelanggannya dan bertindak demi kepentingan pelanggan, serta memberikan perhatian personal kepada para pelanggan dan memiliki jam operasi yang nyaman.

3. Reliabilitas(reliability), berkaitan dengan kemampuan perusahaan untuk memberikan layanan yang akurat sejak pertama kali tanpa membuat kesalahan apapun dan menyampaikan jasanya sesuai dengan waktu yang disepakati.

4. Daya tanggap (responsiveness), berkenaan dengan kesediaan dan kemampuan para karyawan untuk membantu para pelanggan dan merespons permintaan mereka, serta menginformasikan kapan jasa akan diberikan dan kemudian memberikan jasa secara cepat.

5. Jaminan (assurance),yakni perilaku para karyawan mampu menumbuhkan kepercayaan pelanggan terhadap perusahaan dan perusahaan bisa menciptakan rasa aman bagi para pelanggannya. Jaminan juga berarti bahwa para karyawan selalu bersikap sopan dan menguasai pengetahuan dan keterampilan yang dibutuhkan untuk menangani setiap pertanyaan atau masalah pelanggan.

\section{Kepuasan Nasabah}

Sebenarnya konsep kepuasan nasabah masih bersifat abstrak. Pencapaian kepuasan dapat merupakan proses yang sederhana, maupun kompleks dan rumit,dalam hal ini peranan setiap individu dalam service enconter sangatlah penting dan berpengaruh terhadap kepuasan yang dibentuk.Sejumlah pakar memberikan devenisi kepuasan atau ketidak puasan nasabah. Menurtu Tjiptono dan Chandra (2005:197), mendefinisikan sebagai respon nasabah terhadap evaluasi ketidak sesuaian (Disconfirmation) yang dipersepsikan antara harapan sebelum pembelian atau norma kinerja lainnya dan kinerja aktual produk yang dirasakan setelah pemakaiannya.Tjiptono(2007:349) mengatakan bahwa kata kepuasan (satisfaction) berasal dari bahas latin "satis" (berarti cukup baik, memadai) dan "facio" (melakukan atau membuat sesuatu memadai). Kepuasan dapat diartikan sebagai upaya pemenuhan sesuatu atau membuat sesuatu memadai.Definisi tentang kepuasan nasabah bervariasi, seperti kajian literatur tentang kepuasan nasabah yang dilakukan oleh Tjiptono (2007:349).Namun demikian memiliki kesamaan dalam hal tiga komponen utama:

1) Kepuasan nasabah merupakan respons (emosional atau kognitif)

2) Respons tersebut menyangkut fokus tertentu (ekspektasi, produk, pengalaman konsumen, dan seterusnya).

3) Respons terjadi pada waktu tertentu (setelah konsumsi, setelah penilaian produk/jasa, berdasarkan pengalaman akumulatif, dan lain-lain) 


\section{Kerangka Pemikiran}

Sebuah perusahaan akan dianggap sukses dalam jangka panjang ialah perusahaan yang dapat memuaskan semua kebutuhan konsumennya dalam segi pelayanan, sebab kepuasan atau ketidak puasan konsumen akan suatu produk dan pelayanan akan mempengaruhi perilaku dari pembeli selanjutnya. Kualitas sangat berpengaruh pada kepuasan pelayanan, karena pelayanan yang baik, akan memberi dampak positif bagi perusahaan, dalam penelitian ini yang menjadi fokus utama dalam kualitas layanan demi memenuhi harapan pelanggan adalah penggunaan jasa dari PT. Mandala Multi Finance Cabang Palu. Berdasarkan pemaparan tersebut, maka dapat digambarkan kerangka pemikiran, seperti pada Gambar 1 berikut ini:

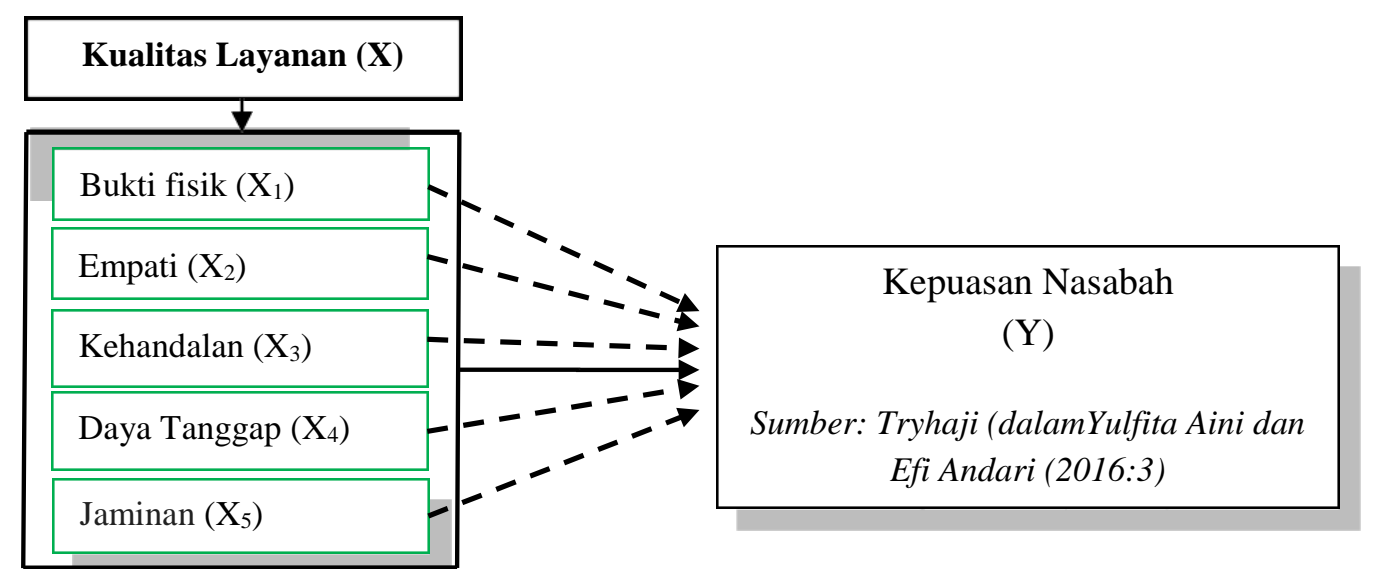

Sumber: Sinambela (2011:7)

\section{Gambar 1 Kerangka Pemikiran}

\section{Hipotesis}

Hipotesis penelitian ini berdasarkan latar belakang masalah, landasan teori dan penelitian sebelumnya, maka hipotesis penelitian ini adalah sebagai berikut:

1. Kualitas layanan yang terdiri dari : bukti fisik, empati, kehandalan, daya tanggap, jaminan, secara serempak bepengaruh signifikan terhadap kepuasan nasabah PT. Mandala Multi Finance Cabang Palu.

2. Bukti fisik berpengaruh signifikan terhadap kepuasan nasabah PT. Mandala Multi Finance Cabang Palu.

3. Empati berpengaruh signifikan terhadap kepuasan nasabah PT. Mandala Multi Finance Cabang Palu.

4. Kehandalan berpengaruh signifikan terhadap kepuasan nasabah PT. Mandala Multi Finance Cabang Palu.

5. Daya tanggap berpengaruh signifikan terhadap kepuasan nasabah PT. Mandala Multi Finance Cabang Palu.

6. Jaminan berpengaruh signifikan terhadap kepuasan nasabah PT. Mandala Multi Finance Cabang Palu.

\section{METODE PENELITIAN}

Jenis penelitian yang digunakan adalah deskriptif-kausal. Penelitian deskriptif digunakan dalam menggambarkan dan menganalisis hasil penelitian tetapi tidak digunakan dalam membuat kesimpulan yang lebih luas. (Sugiyono, 2007:29). Sedangkan penelitian kausal digunakan dalam membuktikan hipotesis melalui perhitungan- perhitungan dan analisis terhadap hasil penelitian, dan hasilnya dapat digunakan dalam membuat kesimpulan, berupa temuan yang digunakan sebagai masukan bagi pembuatan keputusan manajemen (Malhotra, 2005:90), dalam maksud pengujian hipotesis tiap 
pendekatan penelitian yang digunakan adalah penelitian sebab-akibat (kausal), yaitu hubungan yang bersifat mempengaruhi antara dua variabel atau lebih.

\section{Populasi dan Teknik Penarikan Sampel}

\section{a). Populasi}

Populasi adalah gabungan dari seluruh elemen yang bernentuk peristiwa, hal atau orang yang memiliki karakteristik serupa yang menjadi pusat perhatian penelti. Populasi dalam penelitian adalah masyarakat Kota Palu yang menggunakan jasa PT.Mandala Multi Finance Cabang Palu. Jumlah populasi dalam penelitian ini tidak dapat diketahui dengan pasti, karena terdapat nasabah yang berulang kali melakukan transaksi.

\section{b). Teknik Penarikan sampel}

Teknik penarikan sampel adalah dengan menggunakan probability sampling, yaitu teknik pengambilan sampel yang tidak memberi peluang/kesempatan sama bagi setiap unsur atau anggota populasi untuk dipilih menjadi sampel.Hal ini dilakukan karena mengingat keterbatasan waktu yang ada. Metode pengambilan sampelnya menggunakan purposive sampling, yaitu teknik penarikan sampel dengan kriteria tertentu. Sugiyono (2014:174) memberikan saran-saran tentang ukuran sampel untuk penelitian yaitu: bila dalam penelitian akan melakukan analisis dengan multivariate (korelasi/regresi berganda misalnya), maka jumlah anggota sampel minimal 10 kali dari jumlah variabel yang diteliti. Misalnya variabel penelitiannya ada 5 (independen + dependen), maka jumlah anggota sampel $=10 \times 5=50$, Sugiyono (2014:74).Jumlah variabel dalam penelitian ini adalah 6 variabel yang terdiri dari variabel independen (bukti fisik, empati, kehandalan, daya tanggap dan jaminan) dan variabel dependen (kepuasan konsumen).Jumlah sampel yang akan ditentukan oleh peneliti $15 \times 6=90$ responden.

\section{Defenisi Operasional Variabel}

Menurut Sugiyono (2013:58) menyatakan bahwa variabel penelitian ialah segala sesuatu yang berbentuk apa saja yang ditetapkkan oleh penelliti untuk dipelajari sehingga diperoleh informasi tentang hal tersebut, kemudian ditarik kesimpulan. Klasifikasi Variabel penelitian ini dibagi menjadi dua yaitu variabel independen dan dependen. Maka variabel independen dalam penelitian ini adalah kualitas layanan. Sedangkan variabel dependen dalam penelitian ini adalah kepuasan nasabah.

\section{1) Kualitas Layanan (X)}

Kualitas layanan adalah tingkat keunggulan pelayanan yang dapat memenuhi keinginan pelanggan yang diberikan oleh para karyawan perusahaan, dan kualitas pelayanan adalah segala sesuatu yang diharapkan oleh konsumen agar perusahaan dapat memenuhi keinginan dan kebutuhan konsumen.variabel kualitas terdiri dari beberapa dimensi yaitu:

a. $\mathrm{X}_{1}=$ Tangible (bukti fisik)

Adalah penampilan fisik yang dimiliki PT.Mandala Multi Finance Cabang Palu dalam hal ini penataan interior, eksterior serta kostum dan kerapihan para karyawan/karyawati perusahaan. Indikator yang digunakan untuk mengukur variabel ini: memiliki tempat parkir yang baik, penataan interior yang menarik, kerapihan seluruh karyawan dalam bekerja.

b. $\mathrm{X}_{2}=$ Empathy (empati)

Adalah perhatian pihak manajemen PT. Mandala Multi Finance Cabang Palu dan karyawan/karyawati yang bersifat individual atau pribadi kepada para nasabah/konsumen dan berupaya untuk memahami keinginan para nasabah/konsumen. Indikatornya terdiri dari karyawan sangat perhatian terhadap nasabah dalam memahami keinginan nasabah, kesungguhan karyawan dalam menanggapi keluhan nasabah, kemampuan karyawan dalam menjalin komunikasi dengan nasabah.

c. $\mathrm{X}_{3}=$ Reliability (kehandalan)

Adalah kemampuan para karyawan/karyawati PT. Mandala Multi Finance Cabang Palu untuk memberikan pelayanan dengan akurat dan terpercaya sesuai dengan harapan nasabah/konsumen, serta 
pelayanan yang sama bagi semua nasabah/konsumen dan tanpa kesalahan. Indikator yang digunakan dalam dimensi ini: prosedur pelayanan yang tepat, prosedur pelayanan yang tepat, transaksi nilai barang yang cepat, transaksi nilai barang sangat tepat, pembayaran yang akurat dan tepat.

d. $\mathrm{X}_{4}=$ Responsiveness (dayatanggap)

Adalah kebijakan pihak manajemen PT. Mandala Multi Finance Cabang Palu serta pengetahuan, keramahan dan kemampuan para karyawan/karyawati yang ada untuk memberikan pelayanan yang tepat dan cepat (responsif) kepada para nasabah/konsumen sehingga menimbulkan kepercayaan dan keyakinan bagi para nasabah/konsumen.

e. $\mathrm{X}_{5}=$ Assurance $(\mathrm{jaminan} / \mathrm{kepastian})$

Adalah kepastian berupa kemampuan karyawan/karyawati untuk meyakinkan dan menjaga kepercayaan terhadap janji yang telah diucapkan kepada nasabah/konsumen. Indikator yang digunakan dalam dimensi ini: kemampuan karyawan dalam meyakinkann nasabah, kemampuan karyawan dalam menjaga kepercayaan dari nasabah, kemampuan karyawan dalam meningkatkan kinerja guna meningkatkan jaminan kepada nasabah.

\section{2). Kepuasan Nasabah (Y)}

Kepuasan nasabah adalah tingkat perasaan senang atau kecewa seseorang setelah membandingkan kinerja atau hasil yang ia rasakan dibandingkan dengan harapan. Umumnya harapan nasabah merupakan perkiraan atau keyakinan konsumen tentang apa yang akan diterimaa bila ia membeli atau mengonsumsi suatu produk.

\section{Metode Analisis}

Untuk menjawab permasalahan serta hipotesis yang diajukan digunakan alat analisis statistik, yaitu Regresi Berganda (Multiple Linear Regression). Adapun penggunaan regresi linear berganda terkait dengan permasalahan dan hipotesis yang diajukan dalam penelitian pengaruh variabel independen $(\mathrm{X})$ terhadap variabel dependen (Y) melalui bantuan SPSS 16.0.

\section{HASIL DAN PEMBAHASAN}

\section{Hasil}

Berikut hasil mengenai pengaruh variabel bebas baik secara serempak maupun parsial yang diolah SPSS 16.0 . Adapun penggunaan regresi linear berganda terkait dengan permasalahan dan hipotesis yang diajukan dalam penelitian pengaruh variabel independen $(\mathrm{X})$ terhadap variabel dependen $(\mathrm{Y})$, dengan analisis regresi linier berganda seperti pada tabel 2 berikut ini:

Tabel 2

Hasil Uji Analisis Regresi Linear Berganda

\begin{tabular}{|c|c|c|c|c|c|c|c|}
\hline \multicolumn{8}{|c|}{ Dependen Variabel Y = Kepuasan Nasabah } \\
\hline \multirow{2}{*}{\multicolumn{3}{|c|}{ Variabel Independen }} & \multicolumn{2}{|c|}{$\begin{array}{c}\text { Unstandardized } \\
\text { Coefficients }\end{array}$} & \multirow{2}{*}{$\begin{array}{c}\text { Standardized } \\
\text { Coefficients }\end{array}$} & \multirow[t]{2}{*}{$\mathbf{t}$} & \multirow[t]{2}{*}{ Sig. } \\
\hline & & & B & Std. Error & & & \\
\hline \multirow{6}{*}{1} & (Constant) & & .313 & .226 & & 1.383 & .170 \\
\hline & $\mathrm{X}_{1}$ (Bukti Fisik) & & .074 & .036 & .130 & 2.075 & .041 \\
\hline & $\mathrm{X}_{2}$ (Empati) & & .120 & .042 & .197 & 2.884 & .005 \\
\hline & $\mathrm{X}_{3}$ (Kehandalan) & & .107 & .046 & .162 & 2.296 & .024 \\
\hline & $\mathrm{X}_{4}$ (Daya Tanggap) & & .269 & .054 & .296 & 5.015 & .000 \\
\hline & $\mathrm{X}_{5}$ (Jaminan) & & .354 & .066 & .384 & 5.343 & .000 \\
\hline \multicolumn{2}{|c|}{ Multiple R } & Sig. F & $=0.000$ & Adjusted & $\mathrm{R}$ Square $=0$ & 64 & $\alpha=0,05$ \\
\hline
\end{tabular}




\section{Pembahasan}

\section{a). Bukti Fisik $\left(X_{1}\right)$}

Berdasarkan hasil penelitian ini, indikator-indikator yang digunakan untuk mengukur bukti fisik berpengaruh signifikan terhadap kepuasan nasabah PT. Mandala Multi Finance Cabang Palu. Hal ini menunjukan bahwa bukti fisik PT. Mandala Multi Finance Cabang Palu merupakan faktor penting yang menunjang kepuasan nasabah.

b). Empati $\left(\mathrm{X}_{2}\right)$

Berdasarkan hasil penelitian ini, indikator-indikator yang digunakan untuk mengukur empati berpengaruh signifikan terhadap kepuasan nasabah PT. Mandala Multi Finance Cabang Palu. Hal ini menunjukan bahwa empati dapat mempengaruhi kepuasan nasabah PT. Mandala Multi Finance Cabang Palu.

c). Kehandalan $\left(\mathrm{X}_{3}\right)$

Berdasarkan hasil penelitian ini, indikator-indikator yang digunakan untuk mengukur kehandalan berpengaruh signifikan terhadap kepuasan nasabah PT. Mandala Multi Finance Cabang Palu. Hal ini menunjukan bahwa kehandalan dapat mempengaruhi kepuasan nasabah PT. Mandala Multi Finance Cabang Palu.

d). Daya Tanggap $\left(\mathrm{X}_{4}\right)$

Berdasarkan hasil penelitian ini, indikator-indikator yang digunakan untuk mengukur daya tanggap berpengaruh signifikan terhadap kepuasan nasabah PT. Mandala Multi Finance Cabang Palu. Hal ini menunjukan bahwa daya tanggap dapat mempengaruhi kepuasan nasabah PT. Mandala Multi Finance Cabang Palu.

e). Jaminan $\left(X_{5}\right)$

Berdasarkan hasil penelitian ini, indikator-indikator yang digunakan untuk mengukur jaminan berpengaruh signifikan terhadap kepuasan nasabah PT. Mandala Multi Finance Cabang Palu. Hal ini menunjukan bahwa jaminan dapat mempengaruhi kepuasan nasabah PT. Mandala Multi Finance Cabang Palu.

\section{KESIMPULAN DAN SARAN}

\section{Kesimpulan}

Berdasarkan hasil analisis dan pembahasan yang telah dilakukan pada penelitian ini maka dapat ditarik beberapa kesimpulan mengenaiPengaruh Kualitas Layanan Terhadap Kepuasan Nasabah Pada PT. Mandala Multi Finance Cabang Palu, sebagai berikut:

1. Kualitas Layanan, yang terdiri dari Bukti Fisik, Empati, Kehandalan, Daya Tanggap dan Jaminan secara serempak berpengaruh signifikan terhadap kepuasan nasabah pada PT. Mandala Multi Finance Cabang Palu.

2. Bukti Fisik berpengaruh signifikan terhadap kepuasan nasabah pada PT. Mandala Multi Finance CabangPalu.

3. Empati berpengaruh signifikan terhadap kepuasan nasabah pada PT. Mandala Multi Finance Cabang Palu.

4. Kehandalan berpengaruh signifikan terhadap kepuasan nasabah pada PT. Mandala Multi Finance Cabang Palu.

5. Daya Tanggap berpengaruh signifikan terhadap kepuasan nasabah pada PT. Mandala Multi Finance Cabang Palu.

6. Jaminan berpengaruh signifikan terhadap kepuasan nasabah pada PT. Mandala Multi Finance Cabang Palu.

\section{Saran}


1). Kepada PT. Mandala Multi Finance Cabang Palu untuk lebih mengembangkan lagi kualitas layanan, karena pada penelitian ini kualitas layanan memiliki kontribusi yang cukup besar yaitu 76.4\% terhadap kepuasan nasabah di PT. Mandala Multi Finance Cabang Palu, khususnya variabel jaminan, karena sesuai hasil penelitian di lapangan variabel jaminan indikator Memiliki kemampuan dalam meyakinkan nasabahyang paling dominan mempengaruhi kepuasan nasabah pada PT. Mandala Multi Finance Cabang Palu. Sebaiknya PT. Mandala Multi Finance Cabang Palu perlu meningkatkan kemampuan dalammenjaga kepercayaan dari nasabah karenanilaimean nya terendah.

2). Kepada PT. Mandala Multi Finance Cabang Palu diharapkan juga memfokuskan variabel daya tanggap berkaitan dengan kualitas layanan. Hal ini sesuai dengan hasil penelitian dilapangan, dimana daya tanggap indikatorRamah dalam menanggapi keluhan nasabah merupakan faktor kedua yang paling dominan mempengaruhi kepuasan nasabah pada PT. Mandala Multi Finance Cabang Palu. Sebaiknya PT. Mandala Multi Finance Cabang Palu perlu meningkatkankemampuan dalam menyampaikan informasi kepada nasabah karena nilai mean nya terendah.

3). Kepada peneliti selanjutnya disarankan untuk memasukkan variabel lain, selain yang digunakan dalam penelitian ini sehingga lebih dapat mengukur sebab-sebab yang mempengaruhi kepuasan nasabah PT. Mandala Multi Finance Cabang Palu, selain itu juga diharapkan untuk menggunakan ukuran sampel yang lebih besar dari jumlah sampel yang digunakan pada penelitian ini sehingga keakuratan hasil penelitian akan lebih terjamin.

\section{REFERENSI}

Kotler dan Keller. 2009. Manajemen Pemasaran,jilid 1 dan 2edisi 13. Jakarta: Erlangga.

Lupiyoadi Rambat. 2013. Manajemen Pemasaran Jasa. Jakarta: SalembaEmpat.

Lovelock Christopher, Wirtz Jochen, dan Mussry Jacky. 2011. Pemasaran Jasa (Manusia, Teknologi, Strategi). Edisi Ketujuh, Jilid 2, Jakarta: Erlangga.

Malhotra. (2005). Riset Penelitian. Jakarta: Gramedia Pustaka Utama.

Tjiptono, Fandy dan candra, Gregorius, 2005, service, equality and Satisfaction, Yogyakarta.

Tjiptono, Fandy dan Chandra, Gregorius, 2007, Service, Equality and Satisfaction, Edisi keduaYogyakarta.

Schiffman dan kanuk, 2008, Comsumer Behaviour, from http://www.findpdf.net/books/aboutconsumer-behavior-building-marketing-strategy-edisi-11-leon-schiffman-download.html. $\quad$ Di akses pada tanggal 25 september 2017.

Sugiyono, 2007, Metode Penelitian Bisnis, Bandung: CV. Alfabeta.

Sugiyono, 2013, Metode Penelitian Bisnis. Bandung: CV.Alfabeta

Sugiyono(2014).Metode Penelitian Bisnis (Pendekatan. Kuantitatif, Kualitatif, dan R\&D), Cetakan Ke-18.Bandung: Alfabeta. 